\title{
PEMANFAATAN SOSIAL MEDIA SEBAGAI WADAH PROMOSI WISATA KEBUN BUAH NAGA DI RAJA AMPAT
}

\author{
${ }^{1 *}$ Muh Fadli Hasa, ${ }^{2}$ Rendra Soekarta, ${ }^{3}$ Teguh Hidayat Iskandar Alam, \\ ${ }^{4}$ Rais Dera Pua Rawi, ${ }^{5}$ Muhammad Rizki Setyawan, ${ }^{6}$ Siti Nur Kayatun \\ 1.2.3.5.6Fakultas Teknik, Universitas Muhammadiyah Sorong, Indonesia \\ ${ }^{4}$ Fakultas Ekonomi, Universitas Muhammadiyah Sorong, Indonesia \\ Email : fadli.hasa@um-sorong.ac.id
}

\begin{abstract}
ABSTRAK
Kabupaten Raja Ampat tidak hanya memiliki keindahan bawah lautnya tetapi juga memiliki potensi pertanian dan perkebunan, salah satunya yaitu kebun buah naga yang berada di Kelurahan Bonkawir. Kelurahan Bonkawir adalah suatu daerah yang berada di Kabupaten Raja Ampat Provinsi Papua Barat, daerah ini merupakan salah satu daerah yang termasuk dalam pengembangan wilayah oleh pemerintah setempat dalam hal ini di fokuskan pada sektor pariwisata. Perkebunan buah naga, misalnya menjadi salah satu potensi di sektor pertanian dan perkebunan uang bisa meningkatkan kesejahteraan bagi pengelolanya. Semenjak penyebaran covid 19 di papua barat, khusus Raja Ampat, tempat wisata perkebunan buah naga Raja Ampat sepi pengunjung. Berdasarkan hal tersebut menjadikan sebagai dasar pemikiran dari kagiatan pengabdian ini dilakukan, yaitu untuk mendorong peningkatan jumlah pengunjung tempat wisata sehingga dapat memberikan manfaat pemasukan kepada daerah setempat dalam hal ini yaitu kelurahan Bonkawir.
\end{abstract}

\section{Kata Kunci: Raja Ampat, Bonkawir, Buah Naga, Covid 19}

\section{PENDAHULUAN}

Pariwisata adalah segala sesuatu yang berhubungan dengan wisata, termasuk pengusahaan objek dan daya tarik wisata serta usaha-usaha yang terkait dibidang tersebut (UU No. 9 tahun 1990: 2). Pariwisata merupakan industri yang terus berkembang didunia. Sejak lama pariwisata dinegara maju merupakan bagian dari kebutuhan hidup (Purnomo, 2018).

Saat ini pengguna teknlogi informasi, khsusunya internet dari tahun ke tahun selalu mengalami peningkatan. Pusat kajian komunikasi UI melakukan rilis pers tentang hasil survei profil pengguna internet di Indonesia, hasil survei ini merupakan hasil kerja sama dengan APJII yang merupakan sumber informasi tentang data pengguna internet di Indoensia saat ini. Survei tersebut menyebutkan bahwa jumlah pengguna internet di Indonesia telah mencapai 88,1 juta pengguna. Jumlah pengguna internet yang tinggi menjadikan Indonesia sebagai pasar yang potensial untuk kegiatan bisnis secara online.

Industri pariwisata dan Internet menyediakan ruang untuk menentukan keputusannya membuat perjalanan bagi wisatawan. Karena itu, tidak 
mengherankan jika internet pada dasarnya mengubah cara pencarian informasi perjalanan dan proses penentuan tujuan wisata.

Pemanfaatan media sosial berbasis internet sebagai media komunikasi pariwisata lebih fleksibel dan menguntungkan, sebab penggunaan media seperti ini dirasa lebih mudah, memiliki jangkauan yang luas, dan hemat biaya dalam mengkomunikasikan pariwisata, maka hal tersebut yang membuat media sosial semakin diminati untuk sarana komunikasi dan promosi. Media sosial adalah sebuah media berbasis internet yang memudahkan bahkan memungkinkan penggunanya dapat dengan mudah berpartisipasi, menciptakan dan berbagi pengalaman serta informasi yang dimilikinya Selain Facebook, Twitter, Pinterest, LinkedIn, dan Path yang merupakan beberapa media sosial favorit dimasyarakat Indonesia, salah satu media sosial yang tumbuh dengan cepat adalah Instagram.

Kabupaten Raja Ampat tidak hanya memiliki keindahan bawah lautnya tetapi juga memiliki potensi pertanian dan perkebunan, salah satunya yaitu kebun buah naga yang berada di Kelurahan Bonkawir. Kelurahan Bonkawir adalah suatu daerah yang berada di Kabupaten Raja Ampat Provinsi Papua Barat, daerah ini merupakan salah satu daerah yang termasuk dalam pengembangan wilayah oleh pemerintah setempat dalam hal ini di fokuskan pada sektor pariwisata. Batas wilayah kelurahan Bonkawir yaitu sebelah Barat berbatasan dengan pusat kota Raja Ampat, sebalah timur berbatasan dengan Waigeo, sebelah utara berbatasan dengan kecamatan teluk Mayalibit, sebelah selatan berbatasan dengan Laut (Masombe et al., 2015).

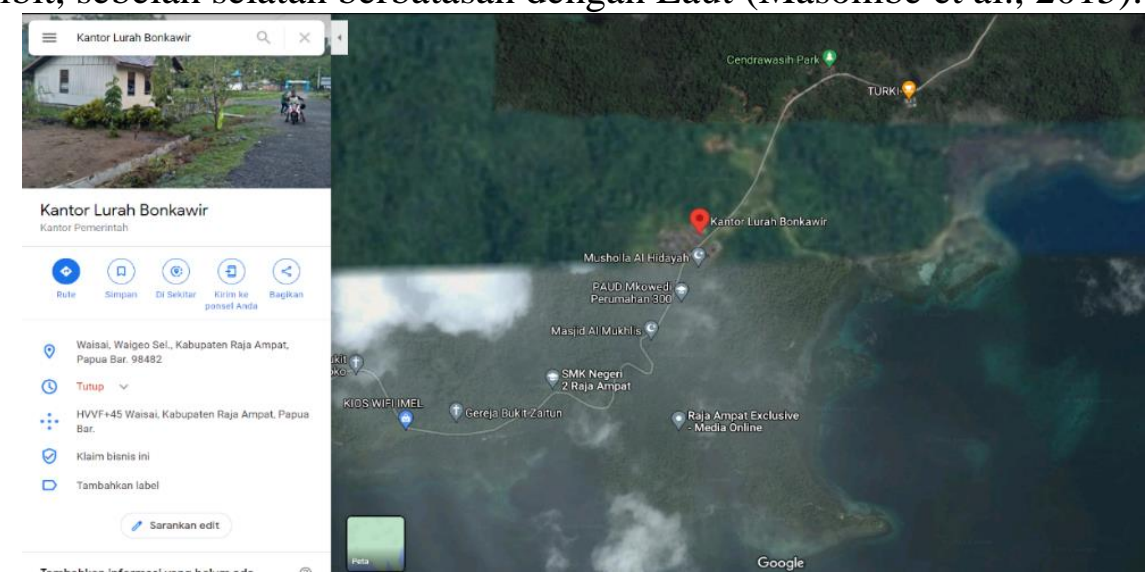

Gambar 1. Peta Wilayah Kelurahan Bonkawir

Sumber : Google Maps (https://goo.gl/maps/R3USDBbyHURhZhk36)

Berdasarkan data Kelurahan, Kelurahan Bonkawir memiliki luas 21,248 km2, dan dari data kependudukan Tahun 2009 jumlah penduduk kelurahan Bonkawir mencapai 688 jiwa dan Tahun 2013 jumlah penduduk mencapai 935 jiwa dengan angka pertumbuhan sebesar $2.82 \%$ per tahun. Kelurahan Bonkawir memiliki 11 RT dan 2 RW.

Perkebunan buah naga terletak tidak jauh dari Kota Waisai, Ibukota Kabupaten Raja Ampat tepatnya di Jalan Waisai-Warsamdin dekat Perumahan Moko Kelurahan Bonkawir. Dari Kota Waisai di tempuh kurang lebih 15 menit dengan menggunakan kendaraan roda dua atau roda empat. 


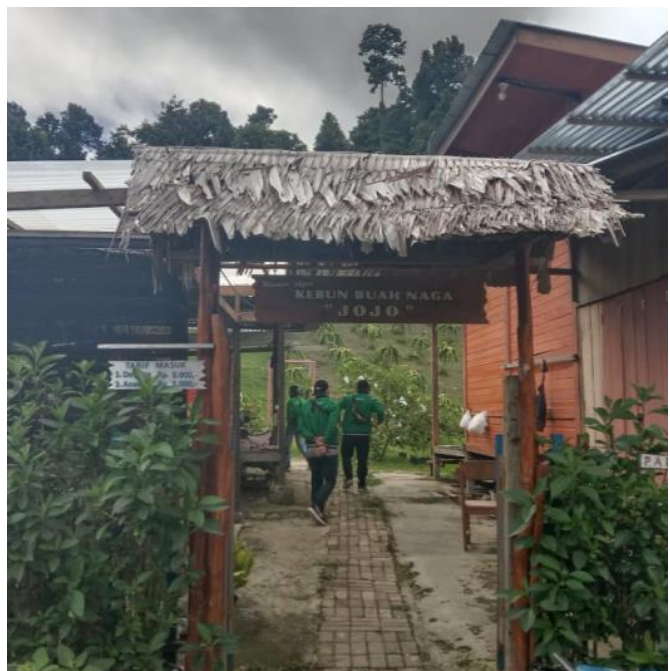

Gambar 2. Lokasi Wisata Kebun Buah Naga

Sumber : Dokumentasi Tim

Semenjak penyebaran covid 19 di papua barat, khusus Raja Ampat, tempat wisata perkebunan buah naga Raja Ampat sepi pengunjung. Berdasarkan hal tersebut menjadikan sebagai dasar pemikiran dari kagiatan pengabdian ini dilakukan, yaitu untuk mendorong peningkatan jumlah pengunjung tempat wisata sehingga dapat memberikan manfaat pemasukan kepada daerah setempat dalam hal ini yaitu kelurahan Bonkawir

\section{METODE PELAKSANAAN KEGIATAN}

Metode pelaksanaan pengabdian masyarakat ini dilakukan dengan cara penentuan masalah melalui proses identifikasi masalah berdasarkan observasi lapangan dan wawancara dengan masyarakat (Irnawati \& Hidaya, 2021). Kemudian dilakukan solusi pemecahan masalah melalui peningkatan kapasitas masyarakat local sebagai peran masyarakat dalam memanfaatkan media sosial berbasis internet sebagai media promosi pariwisata dengan tujuan mampu mendorong peningkatan jumlah pengunjung tempat wisata khususnya wisata kebun buah naga, sehingga dapat memberikan manfaat pemasukan kepada daerah setempat dalam hal ini yaitu kelurahan Bonkawir.

\section{HASIL DAN PEMBAHASAN}

Kegiatan Pengabdian ini dilaksanakan melalui penyuluhan kepada masyarakat pada tanggal 06 April 2021 bertempat di balai kantor Kelurahan Bonkawir, Distrik Waisai Kota. Kegiatan yang dilaksanakan selama 3 hari dan metode yang di gunakan dalam pengabdian ini adalah penyuluhan pada tingkat masyarakat untuk memberikan pemahaman terkait pemanfaatan media sosial sebagai sarana promosi tempat wisata. 


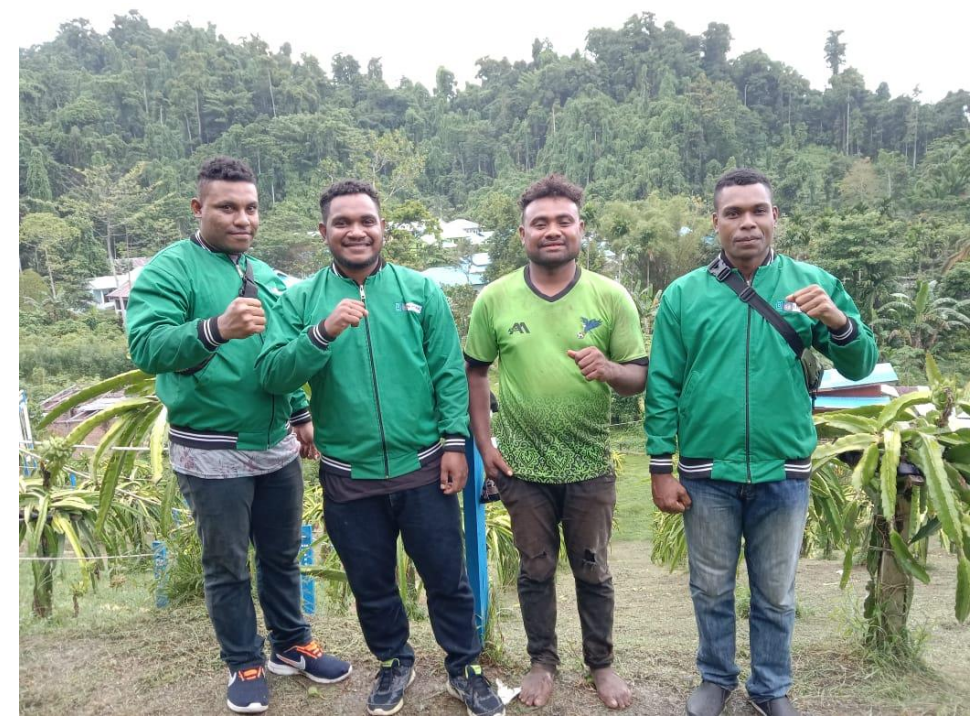

Gambar 3. Foto Bersama Pihak Pengelola Kebun Buah Naga Sumber : Dokumentasi Tim

Proses pelaksanaan juga dilakukan pembuatan konten promosi secara langsung yaitu dalam bentuk desain konten gambar berupa panflet, berikut hasil konten promosi yang telah diposting melalui instagram.

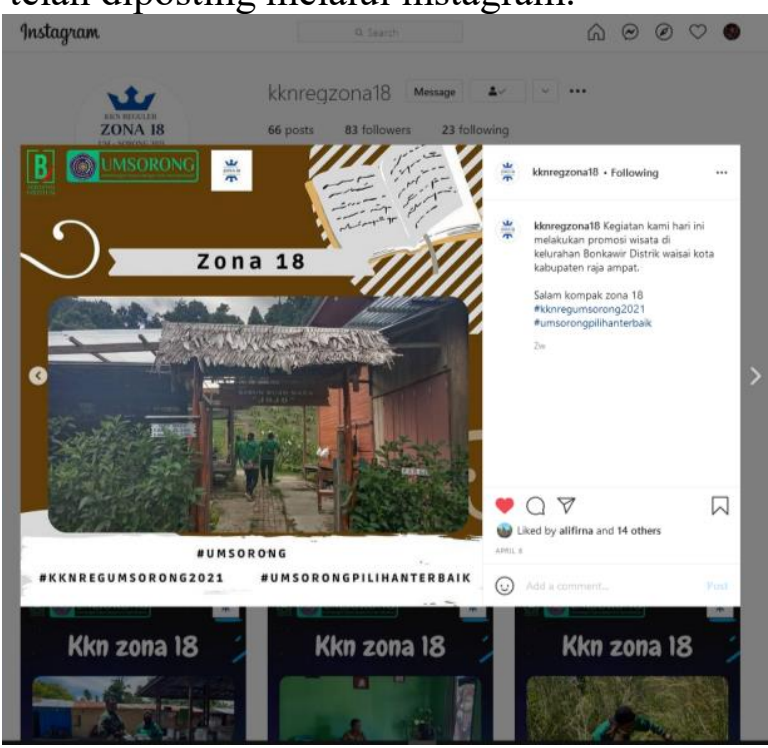

Gambar 4. Hasil Konten Promosi yang Telah Diposting Melalui Instagram Sumber : https://www.instagram.com/p/CNUqFIWH7u6/.

Proses pelaksanaan juga dilakukan pembuatan konten promosi secara langsung yaitu dalam bentuk desain konten video dengan durasi 5 menit 50 detik, berikut hasil konten promosi yang telah diposting melalui instagram. 


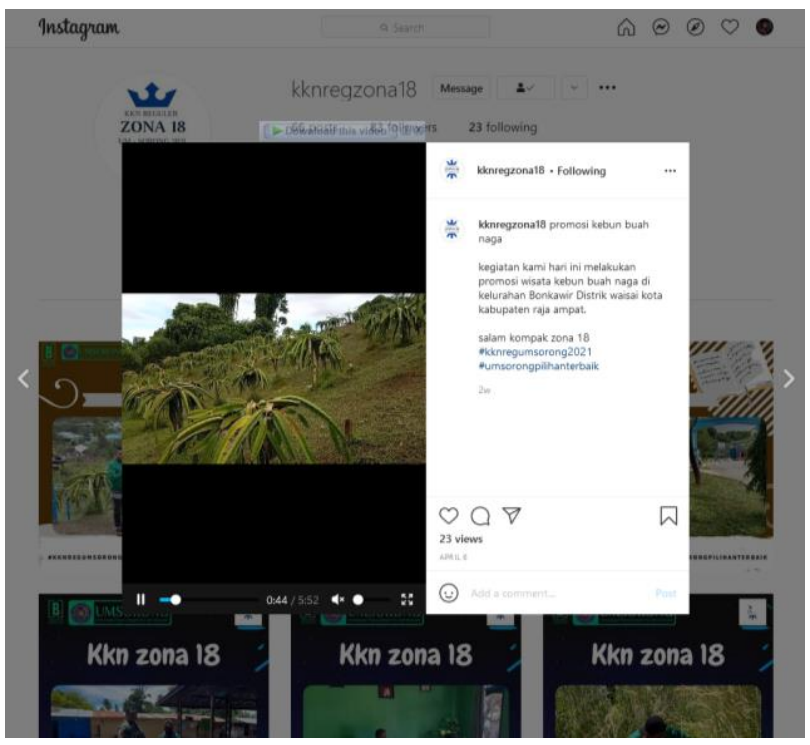

Gambar 5. Hasil Konten Promosi yang Telah Diposting Melalui Instagram Sumber : https://www.instagram.com/p/CNUqFIWH7u6/.

Hasil yang didapatkan berupa konten gambar dan video tersebut kemudian di posting atau disebar luaskan melalu sosial media yaitu instagram. Hasil jangkauan berdasarkan observasi secara langsung pada akun instagram @kknregzon18 yaitu pada konten gambar mendapatkan respon suka (like) berjumlah 14, kemudian pada konten video mendapatkan respon sebanya 23 tayangan. Hal tersebut masih tetap akan bertambah seiring berjalannya waktu serta adanya peran aktif dari pihak wisata untuk membagikan postingan tersebut. Bentuk foto dan video yang dibuat dapat diakses melalu Instagram di link https://www.instagram.com/p/CNUqFlWH7u6/.

\section{SIMPULAN}

Kegiatan Pengabdian ini dilaksanakan melalui penyuluhan kepada masyarakat pada tanggal 06 April 2021 bertempat di balai kantor Kelurahan Bonkawir, Distrik Waisai Kota. Kegiatan yang dilaksanakan selama 3 hari Hasil yang didapatkan berupa konten gambar dan video tersebut kemudian di posting atau disebar luaskan melalu sosial media yaitu instagram. Bentuk foto dan video yang dibuat dapat diakses melalu Instagram di link https://www.instagram.com/p/CNUqFlWH7u6/. Manfaat yang diperoleh yaitu mendorong peningkatan jumlah pengunjung tempat wisata sehingga dapat memberikan manfaat pemasukan kepada daerah setempat dalam hal ini yaitu kelurahan Bonkawir.

\section{DAFTAR PUSTAKA}

Haikal, H., et al. (2021). Penyuluhan Pemanfaatan Media Sosial Bagi Perkembangan Sumber Daya Manusia (SDM) Pada Masyarakat Desa. Jurnal PADMA: Pengabdian Dharma Masyarakat, 1(3). 
Irnawati, I., \& Hidaya, N. (2021). Sosialisasi Masyarakat Tentang Sub Aliran Sungai Di Sekitar Kawasan Hutan Kampung Klaben Distrik Mariat Gunung Kabupaten Sorong. Abdimas: Papua Journal of Community Service, 2(2), 42. https://doi.org/10.33506/pjcs.v2i2.1239

Lewenussa, R., et al. (2019). Pelatihan Fitur Project Dengan Sofware Accurate Pada Mahasiswa Program Studi Manajemen Dalam Rangka Peningkatan Produktifitas Dan Keterampilan Mahasiswa Dalam Dunia Kerja. Abdimas: Papua Journal of Community Service, 1(2), 31-44.

Masombe, N., Binilang, A., \& Halim, F. (2015). Perencanaan Sistem Pelayanan Air Bersih Di Kelurahan Bonkawir Kabupaten Raja Ampat Provinsi Papua Barat. Jurnal Sipil Statik, 3(11), 775-786.

Purnomo, A. (2018). Pemanfaatan Media Sosial Sebagai Media Komunikasi. 102120. file:///D:/LKTI/NASKAH PUBLIKASI.pdf

Rawi, R. D. P., et al. (2019). Pelatihan Pembuatan Keripik Pisang Sebagai Sarana Peluang Bisnis Dan Kreatifitas Mahasiswa Fakultas Ekonomi Universitas Muhammadiyah Sorong. Abdimas: Papua Journal of Community Service, 1(2), 24-30. 